\title{
Culture, narrative and collective trauma
}

\author{
[ B O O K R E V I E W ]
}

Alexander, Jeffrey (2012) Trauma:

A social theory. Cambridge: Polity.

ISBN 978-0-7456-4912-2 pbk. Pages vii + 226

\section{Anthony Collins}

School of Media, Language

and Communication,

Durban University of

Technology,

Durban

"Collective traumas are reflections of neither individual suffering nor of actual events, but symbolic renderings that reconstruct and imagine them. Rather than descriptions of what is, they are arguments about what must have been and what should be. From the perspective of cultural sociology, the contrast between factual and fictional statements is not an Archimedean point. The truth of a cultural script depends not on its empirical accuracy, but on its symbolic power and enactment. Yet, while trauma process is not rational, it is intentional. It is people who make traumatic meanings, in circumstances they have not themselves created and which they do not fully comprehend." Alexander (2012: 4)

Jeffrey Alexander's book explores cultural rather than individual trauma. It is not concerned with the psychology of trauma, but rather the social meanings that historical events come to have for communities. His approach is primarily sociological, exploring the collective construction of meaning, while also drawing on political science and the philosophy of ethics. The importance of the book for those working in the field of psychology might thus not at first be obvious, given that it does not concern itself with the clinical and therapeutic aspects of trauma.

Alexander identifies a prevailing lay theory of trauma, which asserts that certain extreme events destroy 
individual or collective well-being. This lay theory is differentiated into Enlightenment and psychoanalytic strands. The former emphasises trauma as a rational response to extreme events, the latter articulates the psychological defence mechanisms that are triggered by the event. The psychoanalytic model offers a framework for recovery through the reintegration of the repressed (or dissociated, depending on the specific model) experience. In social practice this leads to an emphasis on truth-telling, whereby traumatic events and their effects are recovered into collective consciousness.

A typical example of this would be in countries that had suffered extreme political repression, where the healing process involved some kind of truth commission whereby the denied atrocities of the past were acknowledged, both in their historical veracity and in their traumatic effects on those who endured them. The South African Truth and Reconciliation Commission is a well-known example of this process. There was a dual emphasis on both revealing the previously denied human rights abuses of the Apartheid regime, and giving a public voice to the suffering of those who had endured these horrors. In this understanding there is a sort of elision of the processes of political and psychodynamic repression. The government did not simply commit abuses, it denied them and sought to erase social representation of these events through censorship and further repression. Survivors of these abuses were at the intersection of both their own psychological defences against these horrors, and the absence of public narratives that acknowledged their suffering. The TRC could thus be understood as re-inscribing the truth of these sufferings into both public discourse and personal consciousness, effecting a healing that was both personal and political.

Alexander finds a common fault in both the Enlightenment and psychoanalytic understandings. He argues that they are both built on a naturalistic understanding of trauma. Although many psychoanalytic thinkers may consider this a misinterpretation, he claims that both approaches accept that the traumatic effects of the event are a necessary consequence of its intrinsic horrific nature. The event itself is a historical given, and the traumatic consequences are an inevitable outcome. Against this position, Alexander argues that historical events do not cause collective trauma directly. The collective traumatic effect of the events on a social group arises rather from the collective meanings that event comes to have. This is not to deny the historical events, but to show how its consequent meaning arises from complex and contested processes of social understanding. Thus it is the meaning of the event, rather than its intrinsic nature, that defines the trauma.

This conceptual framing allows Alexander to get on with the real substance of the book: an analysis of the social construction of the collective traumatic nature of specific events. It is not surprising that the bulk of the book is devoted to what is now taken as the event which epitomizes historical trauma: the Holocaust. He offers a detailed and 
thoughtful exploration of how interpretations of the death camps shifted in decades following World War II. Initially they were narrated as one of the 'atrocities of war', another of the range of ghastly events that took place in this war of unprecedented scope and destructiveness. At the time they were not singled out as either especially horrific or especially meaningful, and indeed it seemed that the conditions of the victims were so far from the experiences of the western observers that it was difficult to create an account that enabled an empathic identification with the suffering that had occurred.

Initially this mass murder was articulated within what Alexander refers to as a progressive narrative. This account focussed on the Allied triumph over the Nazi regime. This allowed the destructiveness of the war atrocities to be articulated as part of a triumphal process whose essential outcome was precisely that such events would never happen again. This served especially the US interest in narrating its military involvement as a just war, with a victorious ethical outcome. This gradually gave way to a now more familiar account, through the emergence of the notion of genocide and the re-inscription of the events as "The Holocaust": not a particular genocide of unprecedented scale and horror, but a unique and singular event in human history. This account emphasised not just the overwhelming brutality of the death camps but the intention to completely erase the Jewish people from the human community. It especially served to legitimate the founding of a Jewish state as a physical sanctuary from any such future threat.

As with any competing narrative, this account was stabilized through active processes of memorialisation through specific forms such as Holocaust museums and survivor narratives. An important aspect of this type of narrative is not simply the way in which it represents a historical event, but the collective identities that it produces. Thus founding the state of Israel on a traumatic account of genocide builds into the identity of the state and its citizens the idea that any threat to its identity is a threat of annihilation. This, in turn, legitimates the use of extreme measures to defend that identity against the ascribed threat of annihilation which the account of the founding trauma produces.

Alexander shows how the emergence and stabilization of such an account of trauma depends on the existence of a viable carrier group which has the interests and resources to advance it. At the same time, the difficulty in maintaining control of such an account becomes evident in the ways that critiques of the Zionist state have invoked the notion of genocide to describe its impact on Palestinian people. Similarly, ascriptions of Israel as an "Apartheid state" derive their force precisely on the ways in which South African state racism became accepted as an exemplar of traumatic social policy based on brutal racial inequality. 
Alexander goes on to explore further historical examples of collective trauma: the Rape of Nanjing and the Partition of India and Pakistan. The Rape of Nanjing serves as an interesting example of an atrocity that did not achieve dominant recognition as founding trauma. Although the extraordinarily brutal murder of a quarter of a million Chinese at the hands of the invading Japanese army was a horrific event at the time of the formation of the contemporary Chinese state, it took place in the context of an internal struggle between Nationalists and Communists. As Nanjing was in Nationalist hands at the time of the invasion, an account of the events as a collective trauma did not serve the interests of the ascendant Communist state, as it would have framed Japan rather than the Nationalists as the primary enemy. Thus the Rape of Nanjing was not included in the official account of the emergence of Communist China.

The founding narratives of the states of India and Pakistan are also explored to examine the collective meanings of the enormous ethnic and religious violence that took place in the postcolonial separation of the subcontinent. Nationalist narratives stressed the triumph over colonialism, and the religious necessity of establishing an Islamic state. An emerging challenge to these accounts has been produced by postcolonial thinkers, who have narrated the violence of Partition not simply in terms of traumatic effects on individuals, but also on the lasting antagonisms and dysfunctional forms of social organisation that it has produced. As with the previous examples, these contesting accounts produce a different ethical framing of the situation, and allow for new possibilities of collective social action.

If we were to apply this model to the South African experience of the TRC, it might be argued that the narrative of trauma constructed here focused on serious abuses of human rights related to the political violence of the Apartheid state. This simultaneously foregrounded physical acts of political violence such as murder and torture, to the exclusion of both the structural forms of suffering (poverty, powerlessness, vulnerability, humiliation) and other form of violence (domestic, criminal). This also assisted in the construction of the ANC as the liberating force and the marginalisation of other elements of civil society that have offered serious attempts to engage and resolve social suffering. These constructions in turn allowed for the initial maintenance of economic equality, the increasing authoritarianism of the ANC government, and now the conditions for the disruption of this narrative in the form of a split in the labour movement and the emergence of self-styled economic radicals such as the Economic Freedom Fighters.

Is it also possible to use Alexander's cultural analysis of trauma narratives to reflect on psychological practice in South Africa? Within mainstream Western psychology, the 
notion of trauma is primarily consolidated in the diagnostic category of Post-Traumatic Stress Disorder. Implicit in this notion was the idea of a presumably unproblematic life suddenly disrupted by a psychologically overwhelming event that caused a breakdown of coping mechanisms and produced ongoing psychological dysfunction identified in a specified range of symptoms. This idea has long been contested, both from within South African critical psychology with the alternative idea of Continuous Traumatic Stress and internationally through formulations such as Complex PTSD and Developmental Trauma. All of these challenge the assumption of an isolated traumatic disruption, and explore the possibility of ongoing processes of harm. They allow us to critically engage a range of problems beyond the dominant trauma narratives of criminal violence and sexual assaults, and to consider the structural conditions of social suffering rather than to focus exclusively on the psychology of traumatic events. Thus, while Alexander's book explores the social and political implications of trauma narratives, with a little extra work it may provide useful additional conceptual tools for critical psychologists in South Africa and other contexts in which serious social problems intersect with psychological well-being. 